Г.І. Лагутін ${ }^{1}$, О.М. Романов ${ }^{1}$, А.М. Панченко ${ }^{1}$, О.О. Юр'єв ${ }^{2}$

${ }^{1}$ Харківський національний університет Повітряних Сил ім. I. Кожедуба, Харків

${ }^{2}$ Національний авіаційний університет, Київ

\title{
АНАЛІЗ МОЖЛИВОСТІ ЗАСТОСУВАННЯ ЄМНІСНИХ НАКОПИЧУВАЧІВ ЕНЕРГІЇ В ДИЗЕЛЬНИХ ЕЛЕКТРОСТАНЦІЯХ СИСТЕМ ЕЛЕКТРОПОСТАЧАННЯ КОМПЛЕКСІВ ОЗБРОЄННЯ ТА ВІЙСЬКОВОЇ ТЕХНІКИ В УМОВАХ ВЕДЕННЯ БОЙОВИХ ДІЙ
}

В статті проведений аналіз особливостей запуску двигунів дизель-генераторів в польових умовах, пов'язаних з станом акумуляторів, проаналізовані схемні рімення існуючих способів пуску дизельгенераторів підрозділів військових частин, які розгорнуті в зоні ведення бойових дій. На підставі проведеного аналізу розроблені пропозииії щуодо застосування молекулярних накопичувачів енергії для їх сумісного використання з стартерними акумуляторними батареями в дизельних електростанціях систем електропостачання комплексів озброєння та військової техніки в умовах ведення бойових дій.

Ключові слова: електропостачання військ (сил), зона ведення бойових дій, надійність електропостачання; запуск дизельних двигунів, молекулярний накопичувач енергії.

\section{Вступ}

Постановка проблеми. Однією 3 основних вимог, що пред'являються до Збройних Сил, була i залишається підтримка постійної бойової готовності. Гарантоване, якісне, економне та безпечне постачання електричною енергією озброєння, військової техніки є внеском у підтримання постійної бойової готовності та боєздатності військ (сил) [7]. Значно зростають вимоги до надійності систем електропостачання військових об'єктів в умовах ведення бойових дій. Однією з причин зниження рівня боєготовності електротехнічних засобів $€$ неспроможність електростартерної системи запуску швидко запустити дизельний двигун пересувної електростанції (електроагрегату). Це, в свою чергу, не дає можливості своєчасно забезпечити електричною енергією комплекси озброєння та військової техніки при виконанні ними завдань у зоні ведення бойових дій.

Аналіз останніх досліджень і публікацій. Аналіз виконання завдань Збройними Силами України в польових умовах показав певні проблеми, пов'язані з експлуатацією пересувних джерел електричної енергії, таких як дизельні електростанції та електроагрегати, особливо в умовах низьких температур [8-11]. Зокрема, виникали проблеми 3 надійним запуском дизельних двигунів електростанцій (електроагрегатів) при їх частих пусках внаслідок зниження ступеня заряду стартерних акумуляторних батарей та відсутності достатнього часу на їх підзаряджання. Це, в свою чергу, не дає можливості своєчасно забезпечити електричною енергією комплекси озброєння та військової техніки. Порушення еле- ктропостачання комплексів озброєння та військової техніки може призвести до зриву виконання бойових завдань, загибелі особового складу та знищення військових об'єктів.

Тому актуальним $є$ проведення досліджень, спрямованих на підвищення ефективності систем стартерного пуску дизельних двигунів пересувних електростанцій, що входять до складу систем електропостачання комплексів озброєння та військової техніки, які застосовуються в польових умовах.

Мета статті - Метою роботи є дослідження можливостей щодо використання молекулярних накопичувачів енергії для гарантованого запуску дизель-генераторів, в тому числі в умовах низьких температур, для забезпечення електропостачання військових об'єктів Збройних Сил України, спрямованих на підвищення рівня надійності електропостачання військ в польових умовах.

\section{Виклад основного матеріалу}

Запуск дизельної електростанції (ДЕС) складається 3 запуску двигуна внутрішнього згоряння (ДВ3), збудження генератора, перевірки показників якості електричної енергії та комутації елементів силового кола вихідного розподільного пристрою для видачі електроенергії споживачам [1].

Для запуску ДВЗ зазвичай використовується електростартерна система запуску (ЕС3), для надійної роботи якої необхідно утримувати стартерні акумуляторні батареї (АКБ) в зарядженому стані.

В зимових умовах запуск ДВЗ ускладнюється внаслідок збільшення в'язкості моторної оливи, а також зниження ємності АКБ. 
Проведений аналіз поопераційних витрат часу на підготовку ДЕС до роботи показує, що до $85 \%$ часу при низьких температурах повітря витрачається на передпусковий розігрів ДВЗ.

Для полегшення запуску ДВЗ в умовах низьких температур використовують [3-4]: передпускове прогрівання охолоджувальної рідини рідинними підігрівачами або трубчастими електронагрівачами; нагрівання повітря, яке поступає в камери згоряння двигуна, за рахунок використання електрофакельної системи підігріву або свічок розжарювання. Всі ці способи передбачають наявність АКБ певної ємності, які мають утримуватися в зарядженому стані. В умовах ведення бойових дій утримання АКБ зарядженими, особливо взимку, викликає великі труднощі, тому що під час багатократних запусків двигунів АКБ достатньо сильно розряджаються, а в період між запусками вони не встигають зарядитися [1]. Тому актуальною задачею є пошук таких накопичувачів електричної енергії, які здатні забезпечити як швидке віддавання електричної енергії під час запуску ДВЗ, так і швидке відновлення своїх параметрів під час заряду в період між запусками.

Іншою проблемою є те, що свинцеві кислотні АКБ, які традиційно використовуються в ЕС3, дуже критичні до порушень умов їх застосування за призначенням, технічного обслуговування та зберігання [5]. Неправильна експлуатація АКБ може призвести до зменшення їх електричної ємності, сульфатації або руйнування пластин [6].

Проведений аналіз дозволив зробити такі висновки. Серійні ЕС3 не забезпечують холодні пуски двигунів ДЕС у діапазоні температур навколишнього середовища від мінус $30^{\circ} \mathrm{C}$ до мінус $10^{\circ} \mathrm{C}$. Існуючі способи забезпечення надійності пуску ДВЗ вимагають багато часу для підготовки двигуна до пуску [7; 9].

У зв'язку із цим, для забезпечення ефективного пуску двигуна при низьких температурах доцільно разом з АКБ застосовувати в складі систем електричного запуску альтернативні джерела електричної енергії (АДЕЕ), маючи на меті підвищення пускової потужності ЕС3 у два рази й підвищення ємності джерела електричної енергії в півтора рази.

Таким альтернативним джерелом може бути молекулярний накопичувач електричної енергії (MHEЕ) ємнісного типу [12-15]. МНЕЕ мають ряд переваг при сумісному використанні з свинцевими стартерними АКБ: забезпечують підвищення пускової потужності більш ніж у два рази; мають незалежну від температури навколишнього середовища потужність, що віддається; знімають пікові пускові навантаження, чим забезпечується продовження терміну служби АКБ; мають високі кращі об'ємномасові показники та питомі потужнісні характеристики; мають великий термін служби (до 15 років); зберігають працездатність при низьких температурах; не вимагають технічного обслуговування й ремонту в процесі експлуатації.

Таким чином, для забезпечення подолання підвищеного моменту опору прокручуванню колінчатого вала при холодному пуску двигуна доцільне застосування в складі ЕС3 комбінованого джерела електричної енергії (КДЕЕ), що складається зі свинцевих стартерних АКБ і МНЕ.

Для узагальненої оцінки ступеня відповідності характеристик КДЕЕ технічним вимогам, що висуваються до допоміжних джерел електричної енергії, пропонується ввести векторний показник ефективності $\mathbf{W}(u)$, який ураховує ступінь відповідності КДЕЕ висунутим вимогам за потужністю, за максимальною накопиченою енергією, за масогабаритними характеристиками, за ресурсом (терміном служби), за вартістю тощо.

Для розв'язання задачі про застосування в складі ЕСЗ ДЕС конкретного типу КДЕЕ доцільно використовувати критерій ефективності, в основу якого покладена концепція придатності

$$
W(u) \geq W_{n}, u \in U,
$$

де $W(u)$ - значення показника ефективності $u$-го типу КДЕЕ;

$W_{\text {п }}$ - необхідне значення показника ефективності допоміжного джерела електричної енергії;

$U$ - множина можливих типів допоміжних джерел електричної енергії.

Враховуючи, що прийнятий показник ефективності $\mathbf{W}(u)$ - векторний, а значення необхідного показника ефективності визначається ефективністю існуючих АКБ ДЕС, представляється доцільним застосування такого критерію придатності для КДЕЕ:

$$
\left\{\begin{array}{l}
P_{K(i)} \geq P_{A K Б} ; \\
E_{K(i)} \geq E_{A K Б} ; \\
V_{K(i)} \geq V_{A K Б} ; \\
M_{K(i)} \geq M_{A K Б} \\
R_{K(i)} \geq R_{A K Б} ; \\
B_{K(i)} \geq V_{A K Б} ; \\
i=1 \ldots u
\end{array}\right.
$$

де $P_{K(i)}$ - значення потужності КДЕЕ, Вт;

$E_{K(i)}$ - значення максимальної накопиченої енергії КДЕЕ, Дж;

$$
\begin{aligned}
& V_{K(i)} \text { - значення об'єму КДЕЕ, м³; } \\
& M_{K(i)} \text { - значення маси КДЕЕ, кг; }
\end{aligned}
$$


$R_{K(i)}$ - значення ресурсу (терміну служби), ро-

ків;

$B_{K(i)}$ - значення вартості КДЕЕ, грн;

$i$ - тип КДЕЕ;

$u$ - число прийнятних типів КДЕЕ;

$P_{A К Б}-$ значення потужності існуючих АКБ,

Вт;

$E_{A K Б}-$ значення максимальної накопиченої енергії існуючих АКБ,

$V_{A K Б}-$ значення об'єму існуючих АКБ, м³

$M_{A K Б}-$ значення маси існуючих АКБ, кг;

$R_{A K Б}$ - значення ресурсу існуючих АКБ, років;

$V_{A K Б}-$ значення вартості існуючих АКБ, грн.

Однак виникає проблема вибору кращого типу КДЕЕ із числа придатних, які визначені з використанням обраного критерію придатності. Кращим типом КДЕЕ із числа придатних може бути тип, що має найменшу вартість.

Отже, для визначення кращого типу КДЕЕ потрібне введення додаткового критерію - “ефективність-вартість”, який може бути представлений у вигляді:

$$
\begin{aligned}
& B(i, n) \rightarrow \min , \quad n p u \quad n>n_{n}, \quad T^{\circ}=-35^{\circ} C \\
& u \in N,
\end{aligned}
$$

де $N$ - число придатних типів КДЕЕ, шт.;

$n_{\text {п }}$ - значення необхідної пускової швидкості обертання колінчатого вала дизеля.

Використовуючи критерій “ефективністьвартість”, можна вибрати кращий тип КДЕЕ з числа придатних на стадії технічного проектування, знаючи необхідну пускову швидкість обертання колінчатого вала дизеля при пуску й швидкість обертання, забезпечувану КДЕЕ.

Отже, КДЕЕ слід розглядати як елемент ЕС3, цільовим призначенням якого є розкручування колінчатого вала двигуна внутрішнього згоряння до мінімальної пускової частоти обертання, при якій забезпечуються умови для самозаймання палива.

Методика оцінки ефективності комбінованих джерел електричної енергії містить наступний алгоритм оцінки КДЕЕ за критерієм придатності:

1. Визначення множини КДЕЕ, відповідних за середньою потужністю в стартерному режимі при температурі електроліту мінус $35^{\circ} \mathrm{C}$.

2. Визначення множини КДЕЕ, відповідних за максимальною енергією, з числа попередньо відібраних.

3. Визначення множини КДЕЕ, відповідних за об'ємом, з числа попередньо відібраних.
4. Визначення множини КДЕЕ, відповідних за масою, з числа попередньо відібраних.

5. Визначення множини КДЕЕ, відповідних за терміном служби, з числа попередньо відібраних.

6. Визначення множини КДЕЕ, відповідних за вартістю, з числа попередньо відібраних.

7. Вибір кращого типу КДЕЕ із числа придатних за критерієм “ефективність-вартість”.

Через відсутність власної експериментальної бази, результати експериментальних досліджень наведені $з$ використанням матеріалів [2]. Експериментальні дослідження МНЕЕ проводилися з метою оцінки можливості їх використання для здійснення холодних пусків ДВ3 марки 1Д20, що встановлюються на електроагрегати ДЕС 5И57А, 99Х6, ЕД-60Т/400-1РК, використовувані в діапазоні температур від $50{ }^{\circ} \mathrm{C}$ до $-50{ }^{\circ} \mathrm{C}$. Дослідженням піддавалися MHEЕ марки Титан МСКА-250-30 виробництва TOB TITAN POWER SOLUTION. Випробувані MHEЕ розміщалися в складі системи ЕС3 ДЕС 5И57А, заміняючи дві із чотирьох АКБ 12СТ-85. Випробувані МНЕЕ витримувалися при температурі повітря $5{ }^{\circ} \mathrm{C}$ протягом трьох діб. Температура масла двигуна на момент випробувань визначалася за показниками штатного термометра масла ДВЗ ДЕС 5И57А й складала $5{ }^{\circ} \mathrm{C}$. Температура палива в баках електростанції приймалася рівною температурі навколишнього повітря. У ході випробувань робилися три прокручування двигуна з наступним його пуском. Інтервали між прокручуваннями визначалися тривалістю заряду МНЕЕ від блоку підзаряду щита оперативного живлення ДЕС 5И57А. Можливість холодних пусків ДВ3 ДЕС 5И57А від МНЕЕ типу Титан МСКА-250-30 при температурі $5{ }^{\circ} \mathrm{C}$ оцінювалася за критерієм тривалості пуску двигуна.

Параметри пусків двигуна марки 1Д20 від MHEЕ марки Титан MCКА-250-30 при температурі $5{ }^{\circ} \mathrm{C}$ представлено в табл. 1.

Таблиця 1

Параметри пусків двигуна марки 1 Д20 від МНЕЕ марки Титан МСКА-250-30 при температурі 5 C

\begin{tabular}{|l|c|}
\hline \multicolumn{1}{|c|}{ Найменування параметра } & $\begin{array}{c}\text { Значення } \\
\text { параметра }\end{array}$ \\
\hline $\begin{array}{l}\text { Середня потужність за час пуску } \\
\text { двигуна, кВт }\end{array}$ & 8,5 \\
\hline $\begin{array}{l}\text { Максимальна (пікова) потужність } \\
\text { ЕС3 при пуску двигуна, кВт }\end{array}$ & 35,7 \\
\hline $\begin{array}{l}\text { Середнє значення струму при пуску } \\
\text { двигуна, А }\end{array}$ & 360,9 \\
\hline $\begin{array}{l}\text { Максимальне (пікове) значення } \\
\text { струму при пуску двигуна, А }\end{array}$ & 1164,9 \\
\hline $\begin{array}{l}\text { Середнє значення напруги АКБ при } \\
\text { пуску двигуна, В }\end{array}$ & 20,6 \\
\hline $\begin{array}{l}\text { Мінімальне значення напруги АКБ } \\
\text { при пуску двигуна, В }\end{array}$ & 15,9 \\
\hline
\end{tabular}


Закінчення табл. 1

\begin{tabular}{|l|c|}
\hline Тривалість пуску двигуна, с & 0,9 \\
\hline
\end{tabular}

За результатами експериментальних досліджень установлено, що КДЕЕ, який має у своєму складі МНЕЕ марки Титан МСКА-250-30, забезпечує ефективний холодний пуск ДВЗ 1 Д20 при температурі $5{ }^{\circ} \mathrm{C}$, й так само забезпечує холодне прокручування двигуна без подачі палива тривалістю до 5 с із швидкістю обертання не нижче 80 об./хв. при напрузі бортової мережі не нижче 15,9 В. Тривалість пуску двигуна склала 0,9 с.

У результаті проведених досліджень щодо поліпшення характеристик систем ЕС3 ДВЗ було ви- значено, що застосування МНЕЕ дозволяє не тільки підвищити ефективність запуску ДВЗ ДЕС, але й додатково забезпечити поліпшення якості електричної енергії в системі постійного струму ДЕС й позитивний енергобаланс у всіх режимах роботи системи ЕСЗ і ДЕС.

Функціональна схема ЕС3, що реалізує запуск ДВЗ ДЕС з використанням МНЕЕ, представлена на рис. 1. Особливістю функціональної схеми ЕС3 $є$ пуск двигуна від АКБ разом з МНЕЕ. При цьому передбачається використовувати штатні свинцеві стартерні АКБ.

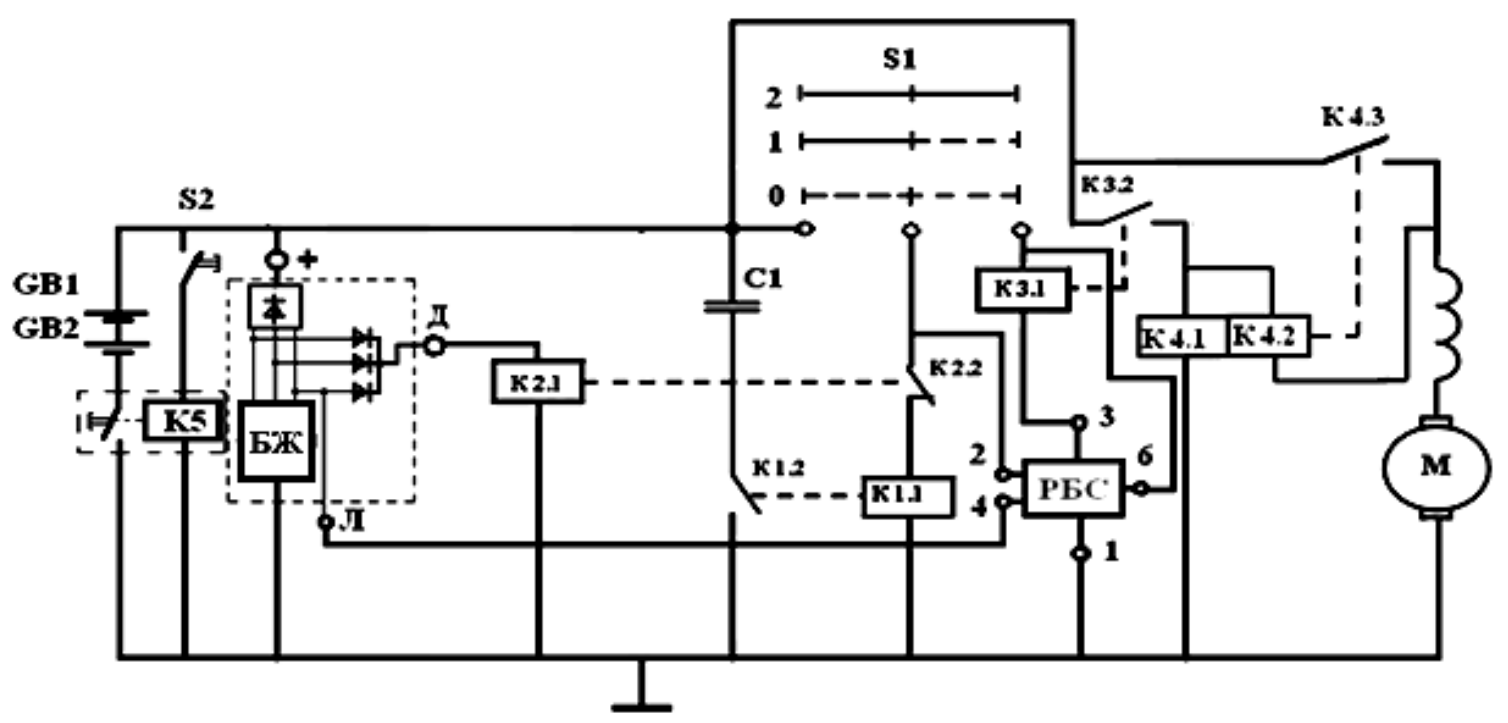

Рис. 1. Принципова електрична схема електростартерної системи запуску електроагрегата ДЕС 5И57А 3 використанням молекулярного накопичувача електричної енергії

Джерело: розроблено авторами за даними [2].

Перевага цього варіанта ЕС3 - максимальна уніфікація із серійною ЕС3, продовження терміну служби АКБ за рахунок зняття пікових навантажень за пусковим струмом.

Аналіз отриманих результатів показав:

а) габаритний об'єм МНЕЕ в складі КДЕЕ порівняний з габаритним об'ємом серійних 24-х вольтових АКБ (габаритний об'єм двох АКБ типу 12СТ85РМ, установлених в ДЕС 5И57А, більш ніж в 3 рази перевищує габаритний об'єм МНЕЕ марки Титан МСКА-250-30), що робить можливим застосування МНЕЕ в ДЕС у складі КДЕЕ при температурах навколишнього середовища до мінус $35^{\circ} \mathrm{C}$;

б) КДЕЕ з МНЕЕ марки Титан МСКА-250-30 за вартістю більш ніж в 1,5 рази дорожче АКБ, однак вони забезпечують холодні прокручування й запуск ДВ3 1 Д20 при температурі до мінус $35^{\circ} \mathrm{C}$ (вартість двох АКБ 12СТ-85 становить 26000 грн.; вартість модуля Титан МСКА-250-30 становить 41050 грн.).

в) за результатами оцінки експлуатаційних показників КДЕЕ встановлено, що вартість експлуата- ції КДЕЕ з МНЕЕ марки Титан МСКА-250-30 знижується на 11 \% при терміні служби АКБ 7,5...10 років, що $\epsilon$ істотним.

Таким чином, MНЕЕ марки Титан МСКА-25030 доцільно використовувати в складі комбінованих вбудованих систем електричного пуску при температурі повітря до мінус $30{ }^{\circ} \mathrm{C}$.

\section{Висновки}

За результатами проведених досліджень установлено:

1. Джерела електричної енергії, що мають у своєму складі МНЕЕ, забезпечують холодне прокручування ДВ3 1 Д20 на малов'язких маслах при температурі мінус $35^{\circ} \mathrm{C}$;

2. Застосування MHЕЕ в складі системи ЕСЗ для пуску двигуна забезпечує підвищення імовірності забезпечення ДЕС 5И57А електричною енергією постійного струму у всіх режимах функціонування на $29 \%$; 
3. Об'ємно-масові й вартісні показники КДЕЕ, що складаються 3 МНЕЕ й свинцевих стартерних АКБ, визначаються в основному параметрами АКБ.

За результатами оцінки техніко-економічної доцільності застосування МНЕЕ були запропоновані технічні рішення щодо поліпшення характеристик EC3 (функціональна схема ЕС3, що забезпечує пуск ДВ3 від молекулярних накопичувачів електричної енергії разом з акумуляторними батареями), виробле- ні практичні рекомендації з їх застосування у складі вбудованої системи ЕС3 з МНЕЕ).

Пропонований у роботі підхід до оцінки й обгрунтування застосування на ДЕС КДЕЕ може бути використаний при виборі параметрів КДЕЕ, що складаються із електрохімічного джерела й MHEE, а також при розробці ЕСЗ ДЕС. В принципі, застосування MHEЕ можливо як у складі вбудованої ЕС3, так і в засобах зовнішнього електричного пуску.

\section{Список літератури}

1. Лагутін Г.І. Аналіз методів визначення характеристик та показників якості систем електропостачання комплексів озброєння та військової техніки / Г.І. Лагутін // Системи озброєння і військова техніка. - 2016. - № 1. - С. 29-34.

2. Євдокимов Є.В. Система електричного пуску двигуна всюдохіда з молекулярним накопичувачем енергії: автореф. дис. канд. тех. наук: 05.09 .03 / С.В. Свдокимов; ДВВКУ (ВІ). - М., 2009. - 27 с.

3. Кононов Б.Т. Вибір показника для оцінювання технічного стану дизель-генератора / Б.Т. Кононов, О.І. Бондаренко // Збірник наукових праць Харківського національного університету Повітряних Сил. - 2017. - № 3(52). C. 113-117.

4. Лагутін Г.І. Удосконалення системи керування засобами автоматизації військових електростанцій систем електропостачання радіолокаційних станцій для потреб АТО / Г.І. Лагутін, В.В. Котов // Системи озброєння і військова техніка. - 2017. - № 2(50). - С. 85-88.

5. Лагутин Г.И. Особенности обоснования характеристик и показателей образцов электротехнических средств систем электроснабжения комплексов вооружения и военной техники/Г.И. Лагутин // Системи озброєння і військова техніка. - 2015. - № 4(44). - С. 21-23.

6. Моніторинг станів операційного середовища та багатоструктурних систем військового призначення при управлінні їх функціонуванням та структурною динамікою / Д.А. Гриб, Б.О. Демідов, Ю.Ф. Кучеренко, О.Г. Матющенко, О.О. Хмелевська // Збірник наукових праць Харківського національного університету Повітряних Сил. - 2019. № 1(59). - C. 14-25. https://doi.org/10.30748/zhups.2019.59.02.

7. Буданов П.Ф. Повышение надёжности функционирования энергообъектов на основе усовершенствования программно-технического комплекса автоматизированной подсистемы аварийной и предупредительной защиты / П.Ф. Буданов, К.Ю. Бровко, П.В. Васюченко // Збірник наукових праць Харківського національного університету Повітряних Сил. - 2016. - № 3(48). - С. 161-167.

8. Нор П.І. Методика оцінки технічного рівня зразків озброєння та військової техніки / П.І. Нор, П.В. Щипанський, С.Ю. Гогонянц // Системи озброєння і військова техніка. - 2014. - № 3(39). - С. 49-53.

9. Денисов А.И. Совершенствование систем бортового электропитания и запуска газотурбинных двигателей вертолетов / А.И. Денисов, Е.А. Бурсала, К.В. Башинский // Системи озброєння і військова техніка. - 2016. - № 4(48). C. $10-15$.

10. Буданов П.Ф. Моделювання ознак аварійності параметрів технологічного процесу об'єктів електроенергетики / П.Ф. Буданов, К.Ю. Бровко // Збірник наукових праць Харківського національного університету Повітряних Сил. 2015. - № 2(43). - С. 84-88.

11. Герасимов С.В. Розробка оптимальної методики контролю параметрів технічних систем за критерієм точності / С.В. Герасимов // Збірник наукових праць Харківського національного університету Повітряних Сил. -2014. - № 1(38). - С. 213-216.

12. Шаша И.К. Выбор критерия оценки эксплуатационной надежности автомобилей / И.К. Шаша, А.О. Иванченко, И.В. Рогозин // Збірник наукових праць Харківського національного університету Повітряних Сил. - 2014. - № 3(40). C. $149-151$.

13. The Official site of EPRI.COM. Unparalleled Expertise, Creativity, and Collaboration to Inform Decisions, Accelerate Innovation, and Benefit Society. - Available at: http://www.epri.com/Pages/Default.aspx.

14. Офіціальний сайт WARDAY.INFO. Военная техника. Автоматизированная система управления. - Available at: http://warday.info/voennaya_tekhnika/1148-avtomatizirovannaya-sistema-upravleniya-73n6-baykal-1.html

15. Офіціальний сайт MILITARY.IN.UA. - Available at: http://guns-military.in.ua/

\section{References}

1. Lahutin, H.I. (2016), “Analiz metodiv vyznachennya kharakterystyk ta pokaznykiv yakosti system elektropostachannya kompleksiv ozbroyennya ta viys'kovoyi tekhniky" [Analysis of methods for determining the characteristics and quality indicators of power supply systems of armaments and military equipment], Systems of Arms and Military Equipment, No. 1, pp. 29-34.

2. Yevdokymov, Ye.V. (2009), "Systema elektrychnoho pusku dvyhuna vsyudokhida z molekulyarnym nakopychuvachem enerhiyi: avtoref. dys. kand. tekh. nauk: 05.09.03" [All-terrain vehicle electric starter system with molecular energy storage], DVVKU (VI), Moscow, 27 p.

3. Kononov, B.T. and Bondarenko, O.I. (2017), "Vybir pokaznyka dlya otsinyuvannya tekhnichnoho stanu dyzel'- 
heneratora" [The choice of an indicator for assessing the technical condition of a diesel generator / B.T. Kononov, OI Bondarenko], Scientific Works of Kharkiv National Air Force University, No. 3(52), pp. 113-117.

4. Lahutin, H.I. and Kotov, V.V. (2017), “Udoskonalennya systemy keruvannya zasobamy avtomatyzatsiyi viys'kovykh elektrostantsiy system elektropostachannya radiolokatsiynykh stantsiy dlya potreb ATO” [Improving the control system of military power plant automation systems for radar power supply systems for the needs of anti-terrorist operation], Systems of Arms and Military Equipment, No. 2(50), pp. 85-88.

5. Lagutin, G.I. (2015), "Osobennosti obosnovaniya kharakteristik i pokazateley obraztsov elektrotekhnicheskikh sredstv sistem elektrosnabzheniya kompleksov vooruzheniya i voyennoy tekhniki” [Features of substantiation of characteristics and indicators of samples of electrotechnical means of systems of power supply of complexes of armaments and military equipment], Systems of Arms and Military Equipment, No. 4(44), pp. 21-23.

6. Hryb, D.A., Demidov, B.O., Kucherenko, Yu.F., Matyushchenko, O.H. and Khmelevc'ka, O.O. (2019), "Monitorynh staniv operatsiynoho seredovyshcha ta bahatostrukturnykh system viys'kovoho pryznachennya pry upravlinni yikh funktsionuvannyam ta strukturnoyu dynamikoyu" [Monitoring the state of the operational environment and multistructural military systems in managing their operation and structural dynamics], Scientific Works of Kharkiv National Air Force University, No. 1(59), pp. 14-25. https://doi.org/10.30748/zhups.2019.59.02.

7. Budanov, P.F., Brovko, K.Yu. and Vasyuchenko, P.V. (2016), "Povyshenye nadyozhnosty funktsyonyrovanyya énerhoob"ektov na osnove usovershenstvovanyya pro-hrammno-tekhnycheskoho kompleksa avtomatyzyrovannoy podsystemy avaryynoy y predupredytel'noy zashchyty" [Improving the reliability of operation of energy facilities on the basis of improving the software and hardware complex of the automated subsystem of emergency and warning protection], Scientific Works of Kharkiv National Air Force University, No. 3(48), pp. 161-167.

8. Nor, P.I., Shchypanskyy, P.V. and Hohonyants, S.Yu. (2014), "Metodyka otsinky tekhnichnoho rivnya zrazkiv ozbroyennya ta viys'kovoyi tekhniky" [Methods for assessing the technical level of samples of weapons and military equipment], Systems of Arms and Military Equipment, No. 3(39), pp. 49-53.

9. Denysov, A.Y., Bursala, E.A.and Bashynskyy, K.V. (2016), "Sovershenstvovanye system bortovoho élektropytanyya y zapuska hazoturbynnykh dvyhateley vertoletov" [Improvement of onboard power supply systems and start-up of helicopter gas turbine engines], Systems of Arms and Military Equipment, No. 4(48), pp. 10-15.

10. Budanov, P.F. and Brovko, K.Yu. (2015), "Modelyuvannya oznak avariynosti parametriv tekhnolohichnoho protsesu ob'yektiv elektroenerhetyky" [Modeling of signs of accident parameters of technological process of electric power facilities], Scientific Works of Kharkiv National Air Force University, No. 2(43), pp. 84-88.

11. Herasymov, S.V. (2014), "Rozrobka optymal'noyi metodyky kontrolyu parametriv tekhnichnykh system za kryteriyem tochnosti" [Development of the optimal method of control of parameters of technical systems by the criterion of accuracy], Scientific Works of Kharkiv National Air Force University, No. 1(38), pp. 213-216.

12. Shasha, Y.K., Yvanchenko, A.O. and Rohozyn, Y.V. (2014), "Vybor kryteryya otsenky ékspluatatsyonnoy nadezhnosty avtomobyley" [Selection of criteria for assessing the operational reliability of cars], Scientific Works of Kharkiv National Air Force University, No. 3(40), pp. 149-151.

13. The official site of EPRI.COM. Unparalleled Expertise, Creativity, and Collaboration to Inform Decisions, Accelerate Innovation, and Benefit Society, available at: www.epri.com/Pages/Default.aspx.

14. The official site of WARDAY.INFO, "Voennaya tehnika. Avtomatizirovannaya sistema upravleniya" [Military equipment. Automated control system], available at: www.warday.info/voennaya_tekhnika/1148-avtomatizirovannaya-sistemaupravleniya-73n6-baykal-1.html.

15. The official site of MILITARY.IN.UA, available at: www.guns-military.in.ua/

\section{Відомості про авторів:}

\section{Лагутін Геннадій Іванович}

кандидат технічних наук доцент

начальник кафедри

Харківського національного університету

Повітряних Сил ім. І. Кожедуба,

Харків, Україна

https://orcid.org/0000-0002-6337-1357

\section{Панченко Анатолій Миколайович}

кандидат технічних наук доцент

доцент кафедри

Харківського національного університету

Повітряних Сил ім. І. Кожедуба,

Харків, Україна

https://orcid.org/0000-0002-1280-2049

\section{Information about the authors:}

\author{
Hennadiy Lahutin \\ Candidate of Technical Sciences \\ Associate Professor Head of Department \\ of Ivan Kozhedub Kharkiv \\ National Air Force University, \\ Kharkiv, Ukraine \\ https://orcid.org/0000-0002-6337-1357
}

\author{
Anatoliy Panchenko \\ Candidate of Technical Sciences Associate Professor \\ Associate Professor of Department \\ of Ivan Kozhedub Kharkiv National \\ Air Force University, \\ Kharkiv, Ukraine \\ https://orcid.org/0000-0002-1280-2049
}


Романов Олександр Миколайович

курсант

Харківського національного університету

Повітряних Сил ім. І. Кожедуба,

Харків, Україна

https://orcid.org/0000-0002-8595-3147

Юр'єв Олександр Олександрович

викладач кафедри

Національного авіаційного університету,

Київ, Україна

https://orcid.org/0000-0003-0619-8663
Oleksandr Romanov

Cadet

of Ivan Kozhedub Kharkiv National

Air Force University,

Kharkiv, Ukraine

https://orcid.org/0000-0002-8595-3147

Oleksandr Yur'yev

Instructor of the Department

National Aviation University,

Kyiv, Ukraine

https://orcid.org/0000-0003-0619-8663

\title{
АНАЛИЗ ВОЗМОЖНОСТИ ПРИМЕНЕНИЯ ЕМКОСТНЫХ НАКОПИТЕЛЕЙ ЭНЕРГИИ В ДИЗЕЛЬНЫХ ЭЛЕКТРОСТАНЦИЯХ СИСТЕМ ЭЛЕКТРОСНАБЖЕНИЯ КОМПЛЕКСОВ ВООРУЖЕНИЯ И ВОЕННОЙ ТЕХНИКИ В УСЛОВИЯХ ВЕДЕНИЯ БОЕВЫХ ДЕЙСТВИЙ
}

\author{
Г.И. Лагутин, А.Н. Панченко, А.Н. Романов, А.А. Юрьев
}

В статье проведен анализ особенностей запуска двигателей дизель-генераторов в полевых условиях, связанных с состоянием аккумуляторов, проанализированы схемные решения существующих способов пуска дизель-генераторов подразделений воинских частей, развернутые в зоне ведения боевых действий. На основании проведенного анализа разработаны предложения по применению молекулярных накопителей энергии для их совместного использования с стартерными аккумуляторными батареями в дизельных электростанииях систем электроснабжения комплексов вооружения и военной техники в условиях ведения боевых действий.

Ключевые слова: электроснабжение войск (сил), зона ведения боевых действий, надежность электроснабжения, запуск дизельных двигателей, молекулярный накопитель энергии.

\section{ANALYSIS OF THE POSSIBILITY OF USING CAPACITIVE ENERGY STORAGE IN DIESEL POWER PLANTS OF POWER SUPPLY SYSTEMS OF WEAPONS AND MILITARY EQUIPMENT COMPLEXES IN COMBAT CONDITIONS}

H. Lahutin, A. Panchenko, A. Romanov, O. Yur'yev

The article deals with the analysis of the peculiarities of starting diesel engines of generating sets in the conditions of warfare, which are related to the state of batteries. In particular, problems with reliable start-up of diesel engines occurred at their frequent start-ups. This is caused by a decrease in the charge of the starter batteries and the lack of sufficient time to recharge them. Disruptions to the power supply of weapons and military equipment can cause military missions, the loss of personnel, and the destruction of military installations. Therefore, it is relevant to conduct research aimed at improving the efficiency of start-up diesel engines systems of mobile power plants in combat conditions. Existing start-up facilities do not provide cold starts for diesel engines at low-temperature generators, and pre-warm-up methods take a long time to prepare the engine for start-up. Therefore, it is advisable to use molecular electric energy storage units together with rechargeable batteries as part of the engine's electric start system to ensure efficient starting of the engine at low temperatures. This should increase the starting power of the engine's electric start system twice and increase the capacity of the power source by half. Schematic solutions of existing methods of starting diesel generators of military units that are deployed in the war zone, analyzed in the work. An approach to the estimation and justification of the use of complex power sources in diesel power plants is proposed in the article. This approach can be used to select the parameters of a complex source of electrical energy, consisting of a battery and a molecular accumulator of electrical energy, as well as the design of systems for the electric start of diesel engines of generating sets. Based on the analysis, proposals for the use of molecular energy storage have been developed. This will allow the use of molecular electric energy storage units in conjunction with starter batteries in diesel power plants of power systems of complexes of armament and military equipment in combat conditions.

Keywords: power supply of troops (forces), combat zone, reliability of power supply, startup of diesel engines, molecular energy storage. 